\title{
Performance of Floriculture Industry in East Africa: What Lessons can Tanzania Learn from Kenya?
}

\author{
Donatha E. Mwase \\ General Studies Department, Arusha Technical College, Arusha, TANZANIA
}

\begin{abstract}
In the recent days Sub-Saharan African counties look at floriculture as a viable alternative to boost their foreign earnings through export of cut flowers. However, while the sector is second largest contributor to foreign earnings for Kenya, Tanzania is yet to fully exploit the potential for both production and export of cut flowers. This paper was set with an aim to make comparative assessment of performance of floriculture industries in Kenya and Tanzania. The study relied mainly on secondary data obtained from International Trade Centre (ITC) database, published previous survey reports and several national policies and strategies. The findings revealed that Kenya was performing better than Tanzania in terms of quantity of cut flowers exported to different destinations in the World and in-terms of value of earnings from export of those flowers. It was observed that while the floriculture sector for both countries had been growing in the past nine years, Kenya's performance was far beyond Tanzania's. Among the major hurdles to the growth of Tanzania's floriculture industry included lack of efficient air transportation, absence of a National Horticulture Policy in place, unorganized farming systems without clusters and foreigners domination of the sector. The paper recommended for a number of measures to improve performance of floriculture industry in Tanzania including need to: (a) formulate national horticulture policy to guide expansion of the sector (b)engage in strategic negotiations with big cargo Airline Companies so that they can frequently land at Kilimanjaro International Airport for easy transportation of cut flowers to the different destinations in the world and (c) launch coordinated efforts by experts from the Tanzania's ministries of agriculture, trade, transportation and finance to draw lessons from Kenya on how to grow floriculture in the country.
\end{abstract}

Keywords: Floriculture, Performance, Kenya, Tanzania, Lessons

\section{INTRODUCTION}

Agriculture has been on top of development agenda in East African countries including Tanzania all through the colonial rule and much so in the recent days. The awakened involvement in agricultural activities among African countries is generally in consonance with World Bank's conviction that agricultural development is the most viable tool to achieve the first millennium development goal of reducing extreme poverty and hunger by 2015 in the region (World Bank, 2007). This view is also supported a large body of evidences suggesting that expansion of agricultural sector is key to economic growth and poverty reduction in most SubSaharan Africa (Christiaensen \& Demery, 2007; Byerlee et al. 2005; DFID, 2005; Dercon, 2009; Diao et al. 2003; Mwabu \& Thorbecke, 2004; Wolgin, 2001). Given that large proportion of the population depends on subsistence farming as the major means of earning life, Rosegrant et al. (2007) argue that there is direct link between agricultural sector and sustainable development in Sub-Saharan African (SSA) countries and in particular East Africa.

In attempts to diversify the agricultural sector, floriculture has emerged as one of the sectors through which East African countries can boost their Gross Domestic Products (GDP). The zeal for countries to engage in floriculture is contributed by the high demand of the same in the developed countries in Europe, America and Asia. This point is well argued by Getu (2009), noting that "flowers are luxurious products with high social value and rarely used for food". Give that the demand for luxurious good has increased in the globe and specifically in the developed countries, floriculture is seen as an economic remedy for many developing countries with favorable geographic conditions (Frank and Cruz, 2001).

Generally, therefore, the farming and export of flowers in Africa has experienced robust growth in the recent days. Some of the Sub-Saharan African countries have been in the lead in this lucrative business. Most of the flowers grown in Africa are exported to European Union (EU). According to EUROSTAT database (EUROSTAT, 2007) Kenya was the leading African exporter of flowers to EU with an export share of 38 percent. Other countries in ranked order include Zimbabwe (5\%), Uganda (3\%), South Africa (2\%), Zambia (2\%), Ethiopia (1\%) and Tanzania (1\%).

This paper emerged out of realization that although Tanzania is one of the most fertile countries in East African region, with specific geographical advantage for cultivation of flowers, still what was produced is quite less compared to the neighboring including Kenya (EUROSTAT, 2007). This situation poses the following question: Why is floriculture in Tanzania is not growing 
as fast as in Kenya? While a number of studies have been conducted in Tanzania on the areas of horticulture (Msogoya and Maerere, 2006; Ndulu and Chakrabarti, 2007, URT, 2003) less has been documented about the performance of floriculture. For instance, Ndulu and Chakrabarti (2007) focus on the factors constraining investment on agriculture in Tanzania but did not specifically concentrate on the performance of floriculture. The then Ministry of Finance (URT, 2003) conducted a survey to investigate investment climate in Tanzania in order to see how more foreign direct investment in agriculture could be attracted but without focus on floriculture. Msogoya and Maerere (2006) conducted a study in floriculture but their focus was specific on the suitability of types of green houses used. Most notably, all of the previous studies mentioned above did not adopt a comparative approach on the performance of floriculture industries in Tanzania with those in Kenya.

The aim of this paper is to provide a comparative assessment of performance of floriculture industries in Kenya and Tanzania. Specifically, the paper focuses on the comparison of those two East African countries in terms of quantity of cut flowers produced, growth in export in the recent years, earnings from export of cut flowers and growth in value of earning between several recent years. Lastly, the paper highlights lessons that Tanzania can learn from Kenya on the growth and sustainability of floriculture industry.

\section{LITERATURE REVIEW}

Getu (2009) defines floriculture as "a discipline of horticulture concerned with the cultivation of flowering and ornamental plants for gardens and for floristry, comprising the floral industry." Floriculture, as an industry, comprises both production and marketing of different varieties of flower and related plants. Taking into account those two aspects, floriculture has been defined as cultivation and marketing of a wide variety of plants and planning materials including parental products like cut flowers, foliage, potted plants, garden plants, nursery stock (trees), flowering leafy, annuals, perennials, flower bulbs and tubers (Van Uffelen, 2005). In this respect, floriculture is inclusive of both flowers and other ornamental trees that can be used to decorate house or office compounds. Floriculture is part of horticulture. This is the reasons why some authors have defined it as a field that is part of horticulture that is concerned with commercial production, marketing, and sale of bedding plants, cut flowers, potted flowering plants, foliage plants, flower arrangements, and noncommercial home gardening (Getu, 2009). In this paper, floriculture is treated as production and export of cut flowers. The consideration here is that most of the floriculture products in Kenya and Tanzania are flowers, especially cut roses.

\section{Floriculture in Kenya}

The evolution of floriculture as a business sector in Kenya can be traced back to 1960 when some European Settlers began exporting flowers to Europe (Hughes, 2004). In Kenya, cut flowers are grown in various geographical areas. The biggest growing region is around Lake Naivasha, which accounts for $44 \%$ of total land undercut flowers (Kiptum, 2005). Other production areas include Thika, Limuru, Nairobi, Nanyuki, Mt.Kenya and Eldorate. There has been expansion in terms of the total land on which cut flowers are cultivated in Kenya. For instance, the total area under cut flower cultivation had increased from around 100 hectors in 2000 to 2,000 hectors in 2009 (Kenya Flower Council, 2009).

In terms of actors, there has also been an increase. By 2005 floriculture in Kenya was dominated by 24 large companies who in sum produced $72 \%$ of all exports from Kenya (Kimtum, 2005) but by 2010 the number of registered companies had increased to 150 (Kenya Flowers Association, 2010). In addition, small holders are an integral part of the actors in the floriculture sector in Kenya. The small companies were concentrated on the production of summer flowers such as Eryngium, Ornithogalum, Papyrus, Lillies, Ammi, Molucella, Asclepias (moby-Dick), Rudbeckia, Euphorbia, Orchids, and Scabiosa. The reason for a concentration in these types of flowers is that they were less labor intensive. The total land used by the small producers was about 20 hectares by 2005 (Kimtum, 2005)

Most of the Kenyan cut flowers are exported to Europe where they are auctioned or sold to whole sellers. The Netherlands is the largest market for the Kenyan flowers (Hale and Opondo 2005). Kenya is among the major flower producers in the world although their position has been changing from one year to another due to climatic conditions and of recent the political crisis following the December 2007 general elections. Nevertheless, the current trends show that Kenya is the third largest producer after the Netherland and Columbia (Rikken, 2011). It has been observed that cut flowers are among the Kenya's top earners of foreign exchange (Ksoll, Macchiavello and Morjaria 2009).

\section{Floriculture in Tanzania}

In Tanzania floriculture, as a business, started in 1987 and it involved cultivation of carnations, euphorbia and amimajus in open fields for export to Europe (Nyambo and Verschoor, 2005; Sutton and Olomi, 2012). The growth of this sector in the initial days was rather slow. It is observed that modern cultivation of cut flowers in the country came five years after when two companies namely Tanzania Flowers and Kiliflora (both owned by the Bruins family) introduced greenhouses alongside initiating the production of roses (Nyambo and Verschoor, 2005). The authors observe further that by 2000, there were only seven companies in the whole 
floriculture industry in Tanzania. Those companies included (a) Kiliflora (b) Tanzania Flowers (c) Kombe Roses which later came to be known as Tengeru Flowers (Tanzanian owned) (d). Hortanzia (e) Horticulture Farms (f) Mount Meru Flowers and (g) La Fleur d'Afrique (jointly owned by Tanzanian and foreigners)

Nonetheless, the expansion of floriculture in Tanzania has been slow compared to the neighboring Kenya. Specifically, the number of actors in the sector has remained low. Sutton and Olomi (2012) observe that the number of companies, which by 2000 were seven have virtually remained unchanged. An important observation, though, is that most of the flower companies in those days and even recently are owned by foreigners. Just like Kenya, most of cut flowers from Tanzania are exported to European. Currently, the Netherlands imports about $90 \%$ of Tanzania flowers (Rikken, 2011). Although there is also a growing local demand for cut flowers in major cities and towns Dar es Salaam, Arusha, Mwanza and Moshi, still the productive capacity of the sector is largely underutilized given that Tanzania has favorable climatic and soil conditions for growing the same.

\section{Factor affecting the performance of floriculture industry in East Africa}

Limited literature available shows that there are several factors that affect floriculture and agriculture in general in Africa. Among them are political instability, limited investment in the sector, shaky policy environment and poor infrastructure. In the past two decades for example the continent has been involved in rampant conflicts, which in turn limit the level of investment on the agricultural sector. Miguel et al., (2004), for example indicate that in the period extending from 1980s to 1900s there were conflicts in 23 out of 43 Sub-Saharan African (SSA) countries. In the recent years, for example, there have been persistent conflicts in the great lakes region in almost all countries surrounding Tanzania including Kenya, Rwanda, Uganda, Burundi and Democratic Republic of Congo. The extended state of unrest in Somalia has also greatly limited the expansion of floriculture especially by discouraging the foreign investors. Political and policy instability in the SSA counties did not only limit locals from engaging fully in agriculture but also made the investors worried of making tangible investments (Ndulu and Chakraborti, 2007; Collier and Gunning 1999; Zhang et al. 2007). A near fetched, and perhaps most relevant, example was post 2007 general election conflict in Kenya. This conflict contributed to deterioration of floriculture in various ways including increased costs of inputs, displacement of workers, insecure and unpredictable transportation of workers and goods from one location to another as well as declined investors' morale (IMF, 2010). In Naivasha, which is the biggest producer of cut flowers in Kenya, the violence contributed to immediate decline on labor turnout (Muhamad, 2009). Similarly, the conflicts contributed to significant decrease in volume of cut flowers exported due to two reasons namely absence of workers and unreliable and unsafe transportation (Ksoll et al., 2010). The authors noted that absence of workers was particularly main reason for the deterioration of the industry since harvesting and handling of flowers is time sensitive.

Unreliable sources of financial services also contributed to poor performance of floriculture sector. This happened when there were no reliable providers of financial services and due to risks associated with financial investment (Zhang et al., 2007). This stance is supported by a study by World Bank in four SubSaharan African countries including Mozambique, Zambia, Malawi and Zimbawe (World Bank, 1999), which revealed that availability and cost of finance had negative impact on profitability and general performance of the agricultural sector at large.

Limited access to finance among actors in floriculture sector was also noted to be one of the major challenges facing the sector in Tanzania (Sutton and Olomi, 2012). The authors observed that most Tanzanian banks considered floriculture as a high-risk sector and so were unwilling to advance loans to its actors. Given this negative consideration the banks had introduced stringent lending conditions to actors in floriculture including collateral of up to $200 \%$ of the requested loan, short repayment periods, short grace periods and high interest rates (Sutton and Olomi, 2012:56)

Inflation is another problem that limits the size of investment and eventually poor performance of the agriculture sector. Ndulu (2007) observes that regular inflation has characterized most of African countries found in the southern part of Sahara desert in the whole period starting from 2000. He indicated that while inflation levels in this region were in the average of 13.3 percent in the period ranging from 2001 to 2004; it shot to 24.3 percent in 2007. Inflation constitutes poor investment environment as it contributes to volatility of returns, unstable financial institutions and eventually poor macroeconomic stability.

Further, evidences suggest that unstable macroeconomic conditions have significant negative impact on the Foreign Direct Investment (FDI) generally and specifically on the investment on floriculture (Taylor, 2003). This fact is corroborated by findings of Tanzania's Investment Climate Survey conducted in 2003 which among other things revealed that 43 percent of respondent firms indicated that macroeconomic instability was the major obstacle to doing business in the country (URT, 2003). Similar findings have also emerged in the neighboring countries of Kenya and Uganda where 45 and 51 percent of respondents firms respectively indicated that macroeconomic instability was a major problem (Butunyi, 2010)

Yet, the role of efficient air transportation cannot be overstated. According to Bolo (2006), efficient air 
transportation was one of the major success factors in the development and prosperity of the floriculture sector in Kenya. The author noted that reliable air transportation and the proximity of large growing areas to Jomo Kenyatta International Airport in particular were key success factors to the performance of the sector especially as far as export logistics were concerned.

\section{METHODOLOGY}

This study adopted a combination of qualitative and quantitative approach. In this approach, the quantitative data obtained from various sources were complemented with qualitative information cited in some of the documents. The adoption of a combined approach was intended so as increased the reliability of data. The study relied mainly on secondary data obtained from various sources including the previous survey reports available at the Ministries of Agriculture for Kenya and Tanzania, Tanzania Horticulture Association (TAHA), International Trade Centre (ITC) and a number of research reports by various authors both in Tanzania and Kenya. Specifically, the study benefited from the following reports

- Global Competitiveness of the Kenyan Flower Industry (2011),

- Kenya Horticulture Development Policy (2012)

- Tanzania Horticulture Development Strategy 2012 2021 (2010)

- Tanzania Agriculture and Livestock Policy (1997)

- Partnership for Market Access; towards a sustainable market-oriented horticultural Sector in Tanzania (2005)

Information obtained from the various documents and internet sources include (a) quantity of cut flower exported to the world by Kenya and Tanzania for several years starting from 2004 to 2012 (b) growth of exports in quantity various years from 2004/05 to 2010/2011 for Kenya and Tanzania (c) value of total cut flowers exports from Tanzania and Kenya in USD from 2004 to 2012 (d) export growth in value between various years from 2004/05/2010/11.

\section{FINDINGS}

\section{QUANTITY OF CUT FLOWERS EXPORTED}

The findings revealed that there was a big difference between Tanzania and Kenya in terms of quantities of cut flowers exported to the different destinations in the world. This was evident in data for various years starting from 2004 to 2012 . Table 1 below presents the findings.

Table 1: Quantity of cut flower exported to the world by Kenya and Tanzania (tons)

\begin{tabular}{|c|c|c|c|c|c|c|c|c|c|}
\hline & 2004 & 2005 & 2006 & 2007 & 2008 & 2009 & 2010 & 2011 & 2012 \\
\hline Kenya & 81,856 & 84,672 & 97,064 & 97,869 & 110,006 & 113,799 & 108,580 & 116,765 & 104,639 \\
\hline Tanzania & 3,573 & 2,759 & 2,109 & 2,464 & 2,754 & 3,008 & 2,700 & 3,227 & 3,634 \\
\hline Difference & 78,283 & 81,913 & 94,955 & 95,405 & 107,252 & 110,791 & 105,880 & 113,538 & 101,005 \\
\hline
\end{tabular}

Source: ITC, Compiled from international trade statistics, 2014
The findings in Table 1 above show that the quantity of cut flowers exported by Kenya to the various destinations in the world was growing, at least, from 2004 to 2009. The findings further show that Kenya's export of cut flowers increased from 81,856 tons in 2004 to 113,799 tons in 2009. In the subsequent years, however, there was a downward trend with the exports reaching 104,639 tons in 2012. Nonetheless, the findings show that the difference between 2004 and 2012 in terms of quantity of cut flowers exported was 22,783 tons. This is a significant difference.

In Tanzania, however, the situation was different. The findings show that there was a downward trend on the quantity of cut flowers exported to the various destinations from 2004 to 2011and only a little rise in 2012. The difference between 2004 and 2012 in terms of quantity of exported cut flowers was 61 tons only. Compared to the Kenya's difference of 22,783 tons, it appears that Tanzania's performance was quite poor. Another important observation from the findings on Table 1 is that the difference between Kenya and Tanzania in terms of quantity of cut flowers exported was increasing as years went on. This is contrary to, perhaps, an ideal situation whereby Tanzanian producers were expected to learn from their neighbors in Kenya in view of improving cut flowers' productivity. Detailed trend analysis is provided in Figures 1 below.

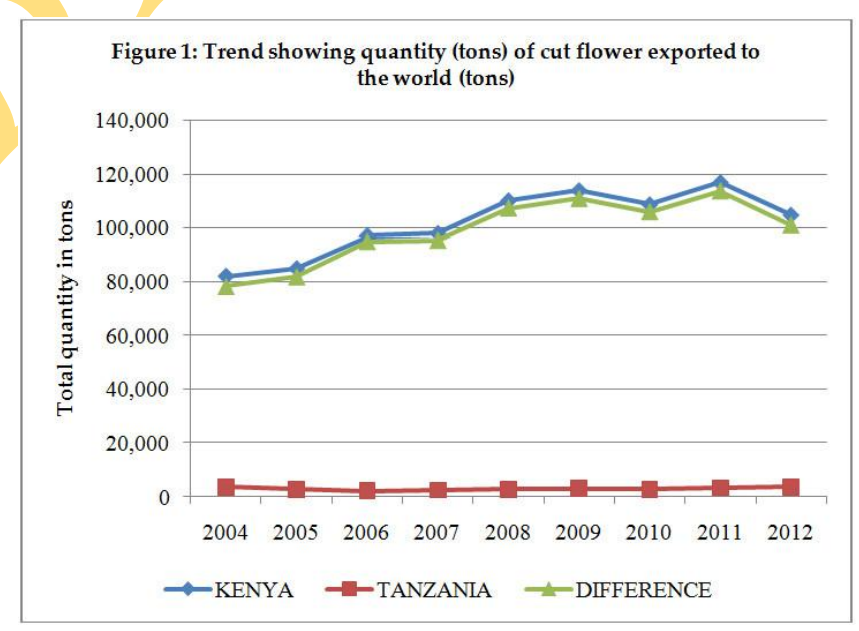

Source: Compiled from ITC, 2014

As already pointed out in the previous paragraph, the differences in annual total cut flowers' exports between Kenya and Tanzania were quite big. Looking at Figure 1 above, it appears that what Tanzania exported was minimal compared to what Kenya produced. This is the reason why the line graph on the 'difference' was closely tied up to that of Kenyan exports.

\section{GROWTH OF EXPORTS IN QUANTITY}

Data compiled from International Trade Centre (ITC) database revealed that growth in terms of quantity of exported cut flowers for Kenya and Tanzania varied significantly. For instance, Kenya was experiencing positive 
growth of the sector in terms of quantities exported for six out of seven years whose data were available.

Table 2: Growth of exports in quantity of exported cut flowers $(\%)$

\begin{tabular}{|c|c|c|c|c|c|c|c|c|}
\hline & $2004 / 05$ & $2005 / 06$ & $2006 / 07$ & $2007 / 08$ & $2008 / 09$ & $2009 / 10$ & $2010 / 2011$ & Average \\
\hline Kenya & 3 & 15 & 1 & 12 & 3 & -5 & 8 & 5.29 \\
\hline Tanzania & -23 & -24 & 17 & 12 & 9 & -10 & 20 & 0.14 \\
\hline
\end{tabular}

Source: Compiled from ITC, 2014

According to the findings presented in Table 2, Kenya registered highest gains of $15 \%$ growth in the quantity of exported cut flowers between 2005 and 2006. Since then, the growth rate decreased in a fluctuating manner. The trend analysis showed that Kenya only experienced negative growth between 2009/10. On average, however, Kenya's export grew at a rate of $5.29 \%$ in the seven years for which data were available.

Tanzania's case was different from that of Kenya. The findings show that between 2004/04 and 2005/06, when Kenya was experiencing positive growth in the quantity of exports, Tanzania was actually experiencing a negative trend. This is clearly shown in the growth rates of -23 and $24 \%$ between 2004/05 and 2005/05 respectively. In the rest of the years except 2009/10 Tanzania experienced positive growth rate. However, in the seven years included in the analysis, the exports of cut flowers from Tanzania were growing at a rate of $0.14 \%$. This growth rate is very low compared to Kenya's growth rate of $5.29 \%$.

\section{EARNINGS FROM EXPORTS OF CUT FLOWERS}

The researcher obtained data on earnings from export of cut flowers for Kenya and Tanzania for several years starting from 2004 to 2012. Data for 2013 for Kenya were not available and therefore the year was exempted from the analysis. Trend showing how the value of cut flowers for both countries performed in those nine years is shown below.

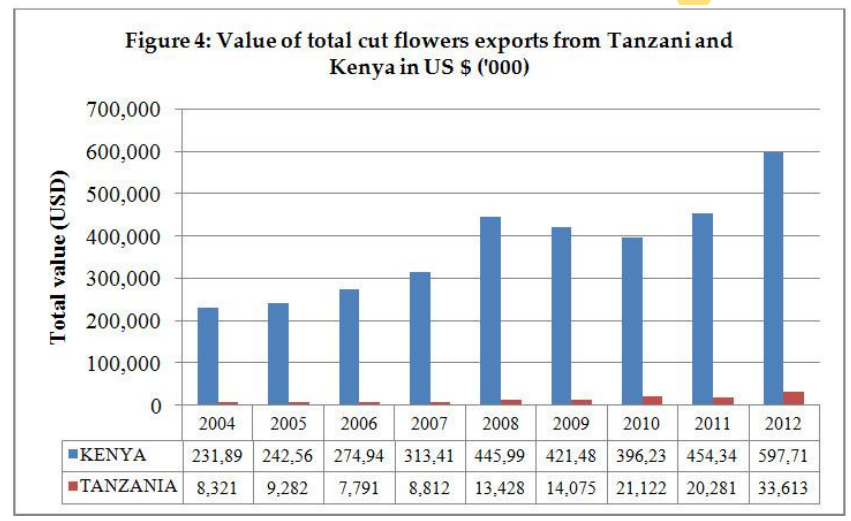

Source: Compiled from ITC, 2014

The findings on Figure 4 revealed that Tanzania's performance on the total value of exported cut flowers for previous 8 years (2004 to 2012) were far lower than that of Kenya. Generally, the findings show that Kenya's foreign earnings due to export of cut flowers increased from \$ 231,890 million in 2004 to $\$ 597,716$ million in 2012 . This is a noticeable achievement given that in a period of less than ten years the foreign earnings from the flower industry had more than doubled.

Likewise, Tanzania's earnings from export of cut flowers also increased year after another. Those earnings increased from \$ 8,321 million in 2004 to \$ 33,613 million in 2012. In those nine years the export earnings from cut flowers quadrupled; the fact that indicates that there was a big achievements in the sector. However, it is worth noting that what Tanzania earned was insignificant compared to earnings by Kenya from the same sector.

\section{EXPORTED GROWTH IN VALUE BETWEEN YEARS}

Data obtained from ITC database showed that the 'between years' export value of cut flowers from Kenya starting from $2004 / 2005$ except for $2007 / 2008$ was decreasing. In some years like 2008/2009 and 2009/2010 the growth was negative. Export growth in value of earnings for Tanzania was also not linear. However, the highest achievements were registered in 2011/2012 when growth was 66\%. Table 3 below presents detailed trend analysis of growth in value of exports for Tanzania and Kenya.

Table 3: Export growth in value between various years (\%)

\begin{tabular}{|c|c|c|c|c|c|c|c|c|c|}
\hline Year & $04 / 05$ & $05 / 06$ & $06 / 07$ & $07 / 08$ & $08 / 09$ & $09 / 10$ & $10 / 11$ & $11 / 12$ & $12 / 13$ \\
\hline Kenya & 5 & 13 & 14 & 42 & -5 & -6 & 15 & $\mathrm{~N} / \mathrm{A}$ & $\mathrm{N} / \mathrm{A}$ \\
\hline Tanzania & 12 & -16 & 13 & 52 & 5 & 50 & -4 & 66 & -59 \\
\hline
\end{tabular}

Source: Compiled from ITC, 2014

\section{LESSONS THAT TANZANIA CAN LEARN FROM KENYA}

Role of efficient air transportation

Lack of efficient air transportation in Tanzania was found to be one of the major hurdles to the growth of the floriculture industry in the country. Particularly, there was no reliable air transportation out of the country to the desired destination in Europe or elsewhere. Although most of the flower farms were located near Kilimanjaro International Airport (KIA), farmers had to export most of their products through Jomo Kenyatta International Airport (JKIA) in Nairobi both because of reliability and freight capacity. According to Tanzania Horticulture Association (TAHA), about $65 \%$ of all flowers exported from Tanzania to different destinations were exported through Nairobi (TAHA, 2008). Reliance on JKIA for export was costly to Tanzania growers in various ways. For instance, during the 2008 political crisis in the neighboring Kenya, the cancellation of flights in Kenya caused a loss of USD 185,000 to Tanzanian growers in only one month (Nkwame, 2008; Ihucha, 2008). Similar view is also demonstrated by Sergeant (2004) noting.

"The industry notes that the main problem that it faces is the cost and capacity of airfreight out of KIA. Many of the exporters prefer to truck their flowers to Jomo Kenyatta International Airport (JKIA) at Nairobi, and put it on freighters flying to Europe. The cost of transport in refrigerated vans to Nairobi adds about USD 0.10 to 0.15/kg to the cost of freight" (Sergeant, 2004:9) 


\section{Role of cluster farming}

In Kenya, cut flowers were produced in clusters which were established as early as in 1980s. In Tanzania, however, production of cut flowers and floriculture at large was dominated by individual growers, who were also limited in numbers. There were several advantages of cluster-based approach in the cut flower production. Bolo (2006) studied Lake Naivasha cut flowers production cluster and established the following advantages of the approach. First, clusters provided opportunities for interaction that in turn stimulated innovation and longrun competitiveness. To elaborate this, Bolo (2006) wrote "In the Lake Naivasha cluster, specifically, farm owners consult each other on technological advancements, new varieties, market information and requirements while employees exchange valuable".

\section{Involvement of indigenous}

The findings of this study revealed that in Kenya, indigenous were involved in two ways. Firstly, they were involved as owners of big companies and secondly as out-growers. According to Chief Executive Officer (CEO) of Kenya Flowers Association, thousands of smallscale growers were involved in the production of cut flowers. In an interview found in their website, she was quoted as follows;

"...There is however a huge number of out-growers. We know of one firm which has in excess of 2,500 small-scale farmers who grow field flowers. We support out-growers because they provide diversity. About $60 \%$ of our flowers are roses. The small-scale farmers grow other types of flowers that do not require capital intensive investments and the kind of technology corporate firms need. Small-scale farmers are also key in supplying the local market, which is a good avenue in branding in Kenya as a flower growing country. People should be able to see the variety of flowers in the public space in the country".

[CEO, Kenya Flowers Association. 10 September, 2012 at https://twiter.com/MadeltInAfrica]

In Kenya, the involvement of indigenous was not only in the production but also in export of flower products to the different destinations in the world. The study found that floriculture industry in Kenya was composed of active 412 flower exporters and among them 54 were large companies while 358 were small (HCDA, 2009). Among the large exporters, $5(9.3 \%)$ were international companies while $49(97.7 \%)$ were local companies. It was also interesting to note that all of the rest 358 small exporters were local Kenyans.

Table 6: Exporters of flowers in Kenya

\begin{tabular}{|c|c|c|c|}
\hline Category & International companies & National Companies & Total \\
\hline Large exporters & $5(9.3 \%)$ & $49(97.7 \%)$ & $54(100 \%)$ \\
\hline Small exporters & $0(0 \%)$ & $358(100 \%)$ & $358(100 \%)$ \\
\hline Total & $5(1.2 \%)$ & $407(98.8 \%)$ & $412(100 \%)$ \\
\hline
\end{tabular}

Source: HCDA, 2009

\section{Role of specific horticulture policy}

The findings of this study revealed that Kenya was seriously dedicated to the promotion of horticulture and floriculture industry in particular. This was evidenced in the specific initiatives to put in place National Horticultural Policy in 2012 (GOK, 2012). This policy's overall objective is "to accelerate and sustain growth and development of the horticulture in order to enhance its contribution towards food security, poverty reduction, employment and wealth creation". Specific attention was given to infrastructure, increased production of quality products and to the institutional strengthening in favor of horticulture expansion in the country. The policy further mentions floriculture export as one of the major earners of foreign income alongside providing employment opportunities for Kenyans.

Tanzania on the other hand lacked specific policy to guide production and export of cut flowers. The findings of this study revealed that the current Tanzanian Agricultural and Livestock Policy (URT, 1997) was more inclined to production for food security. Particularly the policy aimed at assuring basic food security for the nation other than improving national standards of nutrition by increasing output, quality and availability of food commodity. In addition to that, the current national agricultural sector strategy known as "Kilimo Kwanza" (Agriculture First) did not recognize flower farming as an alternative crop that could make remarkable change in the export earnings. Just like the National Agriculture Policy (URT, 1997), the emphasis of "Kilimo Kwanza" was on food crops with the aim of achieving national food security. Similar approach was also demonstrated in the current National Horticulture Development Strategy 2012 - 2021 (HODECT, 2010). Close review of this strategy revealed that floriculture was not featured in any of the six strategies for the growth of horticulture in Tanzania. Surprisingly, floriculture sector was not even mentioned in the first strategy which aimed at promoting horticulture in Tanzania.

\section{DISCUSSION OF FINDINGS}

The findings revealed that floriculture industry in Kenya performed far much better than one in Tanzania. To a large extent, Kenya's performance was enhanced by efficient air transportation system. In Kenya, Kenya Airways (KQ) directly linked the producers of cut flowers with the market in Europe, where most of those products were sold. On this specific aspect, the findings support the literature that Kenya is performing well in the sector due to availability of reliable air Transport (Bolo, 2006). Conversely, the findings indicated that poor performance of the floriculture industry in Tanzania was due to lack of efficient and reliable air transportation compared to the same industry in Kenya. Often, Tanzanian growers had to export floriculture products through Jomo Kenyata International Airport (JKIA). To a reasonable degree, 
therefore, lack of reliable and direct flights from Tanzania to the different cut flower destination markets increased the cost of doing business and therefore discouraged the growth of the sector at large (Nkwame, 2008; Ihucha, 2008; Sergeant, 2004:9). Thus, in spite of good potential of the sector in boosting GDP and sustaining livelihood of flower growers, the growth of floriculture industry in Tanzania was hindered by lack of reliable air transport.

Scattered production of cut-flowers in Tanzania was also noted to be one among major problems facing Tanzanians flower growers as opposed to their counterparts in Kenya who were organized into farmers' clusters. The advantages of cluster-based approach identified by the author include: (a) promotion of cooperation and joint approach in solving problems facing the thereby increasing the bargaining power of the farmers (b) Making easy government intervention and support since the farms in the cluster are located in the same geographical area, and (c) facilitation of marketing and technical assistance between large and small scale farmers. The latter happened when the small farmers were organized to sell through the large scale farmers, arrangement that in turn ensured better quality of flowers. Under cluster approach large scale farmers were also likely to promote small scale farmers through input supplies like better seeds, which otherwise small farmers could not afford on their own. Overall, important point to note is that the clustering approach had implication to small farmers' productivity in the sector (Bolo, 2006). Drawing from the Kenyan experience, it appears that involvement of indigenous is crucial in realizing better performance of floriculture in Tanzania. Particularly, this approach is important in creating sustainable floriculture industry, one that has potentials of reducing poverty among the indigenous. It should be noted here that in Tanzania floriculture can only be realized as an alternative agriculture when the indigenous have been actively involved as opposed to current situation where the players are mainly big foreign companies.

Finally, the findings revealed that Tanzania lacked policy support and institutional frameworks for sustaining the production and marketing of floriculture products. Apparently, the existing agricultural policies were set to promote food security, an inclination that was unlikely to favor production of non-traditional cash crops like cut flowers. Particularly, this may prevent the indigenous companies from venturing in the cut flower production. Expectedly, flower farming (floriculture) should have been featured under the fourth pillar (pillar 4) of the strategy which is on "paradigm shift to strategic framework" where alternative crops are identified (URT, 1997) but this was not the case. Close review of this strategy revealed that floriculture was not featured in any of the six strategies for the growth of horticulture in Tanzania. Surprisingly, floriculture sector was not even mentioned in the first strategy which aimed at promoting horticulture in Tanzania. The findings of this study, therefore, strengthen the conclusion of the previous study by Mashindano et al., (2003) noting that for floriculture sector in Tanzania to achieve its desired objectives and target, there is need for supportive national policies, institutions and legislations.

\section{Conclusions AND Recommendations}

The performance of floriculture industry in Tanzania was persistently poorer than that of Kenya. The latter was performing better in terms of quantity of export, value of export earning and sector's growth rate. Given that the two countries were endowed with equally favorable climatic and geographical conditions, this study concludes that Tanzania had failed to draw good lessons from their neighbor Kenya on how to boost floriculture sector and thus promote foreign earnings. Poor or inefficient air transportation was among the major factors that constrained floriculture sector in Tanzania. Surprisingly, about two thirds of cut flowers from Tanzania were exported through Kenya although the growers were located just close to Kilimanjaro International Airport (KIA). Based on this fact, the study concludes that Tanzania has not given enough attention in the promotion of foreign earnings through strengthening transportation infrastructure for export of non-traditional farm outputs like flowers. Further, the study found out that different from Kenya, Tanzania lacked specific policy to promote floriculture. It was further revealed that although Tanzania had formulated Horticulture Development Strategy 2012-2021, the document did not stipulate specific measures to be taken in order to maximize the opportunities that could be brought about by the sector in terms of its contribution to national GDP. On this ground, this concludes that Tanzania has not demonstrated serious efforts to promote floriculture industry.

In view of the above conclusions, this study recommends for the following measures to be taken by Government of Tanzania. First, The Ministry of Agriculture and Cooperatives Development should formulate specific National Horticulture Policy which will prioritize floriculture industry. Second, the Ministry of Transportation should make strategic negotiations with big cargo Airline Companies so that they can frequently land on Kilimanjaro International Airport for easy transportation of cut flowers to the different destinations in the world. Third, there is need to launch coordinated efforts by experts from the Tanzania's ministries of agriculture, trade, transportation and finance to draw lessons from Kenya on how to grow floriculture in the country. In this approach the experts should come up with a framework on how to improve the performance of the sector. The framework should draw clear linkages of the sectors involved in the whole floriculture production and marketing chain. 


\section{REFERENCES}

Awan, A. (2015). Shifting Global Economic Paradigm. Asian Business Review, 4(3), 35-40. Retrieved from http://journals.abc.us.org/index.php/abr/article/view/Ghafoor

Bolo, M (2006). Knowledge, Technology and Growth: The Case Study of Lake Naivasha Cut flower Cluster in Kenya. World Bank: World Bank Institute

Butunyi, C. (2010). East Africa: Now APA to Offer Political Risk Cover for Kenya, Uganda Firms. Available at: http:/ /allafrica.com/stories/201001250444.html. retrieved on 12/1/ 2014

Byerlee, D., Xinshen, D. \& Jackson, C. (2005). Agriculture, Rural Development, and Pro-Poor Growth: Country Experiences in the Post-Reform Era. Agriculture and Rural Development Discussion Paper 21, Washington, D.C.: World Bank.

Christiaensen, L. and Demery, L. (2007). Down to Earth: Agriculture and Poverty reduction in Africa, Washington D.C.: The World Bank.

Collier, P. and Gunning, J. W. (1999). Explaining African economic performance. Journal of Economic Literature 37: 64 - 111.

Department for International Development (DFID) (2005). Growth and poverty reduction: The role of agriculture. DFID Policy Paper, London: DFID.

Dercon, S. (2009). Rural Poverty: Old Challenges in New Contexts. The World Bank Research Observer, 24(1): 1 - 28.

Diao, X., Dorosh, P., Rahman, M., Meijer, S., Rosegrant, M., Yanoma, Y. and Li, W. (2003). Market opportunities for African agriculture: an examination of demand-side constraints on agricultural growth. Development Strategy and Governance Division Discussion Paper Series 1. Washington, D.C.: IFPRI

Eurostat database, http//epp.eustat.ec.europa.eu.Retrieved on $21 / 01 / 2014$

Frank, B. and Cruz, E. (2001). Flower for Justice, Implementing the International Code of Conduct, Friedrch Ebert Stiftung.

Getu, M. (2009). Mizan Law Rev: Ethiopian Floriculture and its Impact on the Environment 3(2). Available at: http://www.ajol.info/index.php/mlr/article/viewFile/54011 /42554. Retrieved on 12/1/2014

GOK (2012). National Horticulture Policy. Nairobi: Agricultural Sector Coordination Unit

Hale, A. and Opondo, M. (2005). Humanising the Cut Flower Chain: Confronting the Realities of Flower Production for Workers in Kenya, Antipode, 37(2): 301 - 323.

Horticultural Crops Development Authority (HDCA). Available at http:/ / www.hcda.0rg. Retrieved on 7/1/2014

Horticulture Development Council of Tanzania (HODECT) (2010). Tanzania Horticultural Development Strategy 2012-2021. Dar es Salaam: HODECT

Hughes, A. (2004). Accounting for Ethical Trade. Global Community Networks, Virtualism and the Audit Economy. In: Hughes, A and Reimer, S. (eds). Geographies of Commodity Chains, London: Routledge.

Ihucha, A. (2008). Arusha Exporters Secure International Cargo Flight, Sunday Observer, 28 December 2008. Available at http:/ / www.ippmedia.com/ipp/observer/2008/12/28/12885 4.html. Retrieved on 21/01/2014

IMF (2010). World Economic Outlook Update. A policy-driven, Multispeed Recovery. Washington D.C. United State.

Kiptum, B. (2005). Building export markets for Kenyan flowers: Challenges and Opportunities facing small scale flower growers in Kenya. Paper presented at ATPS/CTA national dissemination and exhibition workshop on the flower industry in Kenya on March 31, 2005 in Nairobi.

Ksoll, C., Macchiavello, R. and Morjaria, A. (2010). The Effect of Ethnic Violence on an Export-oriented industry. BREAD working paper. Bureau for Research and Economic Analysis of Development

Ksoll, C., Rocco, M., and Ameet, M. (2009). Guns and Roses: The Impact of the Kenyan Post-Election Violence on Flower Exporting Firms.
Centre for the Study of African Economies Working Paper Series 2009-06, University of Oxford

Mashindano, O.,Vivian K., Specioza, M. and Solomon, B. (2003). Taping Export Opportunities for Horticulture products in Tanzania: Do we have supportive policies and institutional framework? ESRF Policy Brief. Available at.http://esrf.org.tz/docs/horticulture_products.pdf. Retrieved on 20/3/2014

Miguel, E., Satyanath, S. and Sergenti, E. (2004). Economic Shocks and Civil Conflicts: An Instrumental Variable Approach. Journal of Political economy 112 (4)

Msogoya, T. and Maerere, A. (2006). The Flower Industry in Tanzania: Production Performance and Costs. Journal of Agronomy 5 (3): 478-481

Muhammad, A. (2009). Would African Countries Benefit from the Termination of Kenya's Economic Partnership Agreement (EPA) with the EU? An analysis of EU Demand for Imported Roses. Journal of Agricultural Economics 60(1): 200 -238

Mwabu, G. and Thorbecke, E. (2004). Rural development, growth and poverty in Africa. Journal of African Economies, 13 (1): 16 - 65.

Ndulu, B.J. and Chakraborti, L. (2007). Challenges of African Growth: Opportunities, Constraints and Strategic Directions. World Bank Publications

Nkwame, V.M. (2008). Tanzania: Kenya Clashes Backfire on Local Flower Industry, Arusha Times, 11 February 2008

Nyambo, B. and Verschoor, R. (2005). Partnership for Market Access; towards a sustainable market-oriented horticultural sector in Tanzania. Wageningen UR Position paper

Rikken, M. (2011). The Global Competitiveness of the Kenyan Flower Industry.World Bank. Available at: http://www.kenyaflowercouncil.org/pdf/VC5\%20Global\%20 Competitiveness\%20Kenyan\%20Flower\%20Industry\%20\%20ProVerde.pdf Retrieved on 20/3/2014

Rosegrant, M., Rngler, C., Benson, T. Diao, X., Resnick, D., Thurlow, J., Toreror, M., and Orden, D., (2007). Agriculture and Achieving Millenium Development Goals. World Bank. Available at http://www.ifpr.org/pubs/cp/agmdg.asp. Retrieved on 20/3/2014

Sankaran, A., \& Rajkumar, P. (2015). The Dimensions of Industrial Growth in Tamil Nadu, India: Three Decades of Experience. Asian Business Review, 4(1), 19-23. Retrieved from http://journals.abc.us.org/index.php/abr/article/view/Sankaran

Sergeant, A. (2004). Horticultural and Floricultural Exports Constraints, Potential - and an Agenda for Support for the Tanzania Diagnostic Trade Integration Study. World Bank DTIS

Sutton, J. and Olomi, D. (2012). An enterprise map of Tanzania: International Growth Center. London Publishing Partnership.

Tanzania Horticultural Association (TAHA) (2009). Available at http:/ / www.tanzaniahorticulture. Retrieved on 08/02/2014

Taylor, J. (2003). Economic Policies and Investment Risks in Africa. USAfrica Business Summit. Washington, D.C.

URT (1997). Agricultural and Livestock Policy. Dar es Salaam: Ministry of Agriculture and Cooperatives

Wolgin, J.M. (2001). A Strategy for Cutting Hunger in Africa. Report commissioned by the Partnership to Cut Hunger in Africa. Washington D.C.: Partnership to Cut Hunger and Poverty in Africa

World Bank (1999). Southern Africa Agriculture: Gaining Through Regional Collaboration. World Bank Publications, 23.

World Bank (2007). World development report 2008: Agriculture for Development. Washington, DC., USA

Zhang X., Rockmore, M, and Chamberlin, J. (2007). A Typology for Vulnerability and Agriculture in Sub-Saharan Africa. Discussion paper 00734

\section{Internet Sources}

http://www.trademap.org/tradestat/Country_SelProduct_TS.aspx

http://legacy.intracen.org/appli1/TradeCom/TP_EP_CI.aspx?RP=834\&YR=2009

http://www.trademap.org/tradestat/Country_SelProduct_TS.aspxade map.org/tradestat/Country_SelProduct_TS.aspx

https://twiter.com/MadeItInAfrica 